\title{
Role of preoperative intravenous iron therapy to correct anemia before major surgery: a systematic review and meta- analysis
}

Abdelsalam M. Elhenawy ${ }^{1,2^{*}}$ (D), Steven R. Meyer ${ }^{1}$, Sean M. Bagshaw ${ }^{3}$, Roderick G. MacArthur ${ }^{1}$ and Linda J. Carroll ${ }^{4}$

\begin{abstract}
Background: Preoperative anemia is a common comorbidity that often necessitates allogeneic blood transfusion $(A B T)$. As there is a risk associated with blood transfusions, preoperative intravenous iron (IV) has been proposed to increase the hemoglobin to reduce perioperative transfusion; however, randomized controlled trials (RCT) investigating this efficacy for IV iron are small, limited, and inconclusive. Consequently, a meta-analysis that pools these studies may provide new and clinically useful information.

Methods/design: Databases of MEDLINE, EMBASE, EBM Reviews; Cochrane-controlled trial registry; Scopus; registries of health technology assessment and clinical trials; Web of Science; ProQuest Dissertations and Theses; Clinicaltrials.gov; and Conference Proceedings Citation Index-Science (CPCI-S) were searched. Also, we screened all the retrieved reference lists.

Selection criteria: Titles and abstracts were screened for relevance (i.e., relevant, irrelevant, or potentially relevant). Then, we screened full texts of those citations identified as potentially applicable.

Results: Our search found 3195 citations and ten RCTs (1039 participants) that met our inclusion criteria. Preoperative IV iron supplementation significantly decreases ABT by $16 \%$ (risk ratio (RR): $0.84,95 \%$ confidence interval [CI]: 0.71, 0.99, $p=0.04$ ). In addition, preoperatively, hemoglobin levels increased after receiving IV iron (mean difference [MD] between the study groups: $7.15 \mathrm{~g} / \mathrm{L}, 95 \% \mathrm{Cl}: 2.26,12.04 \mathrm{~g} / \mathrm{L}, p=0.004$ ) and at follow-up $>4$ weeks postoperatively (MD: $6.46 \mathrm{~g} / \mathrm{L}, 95 \% \mathrm{Cl}: 3.10,9.81, p=0.0002$ ). Iron injection was not associated with increased incidence of non-serious or serious adverse effects across groups (RR: 1.13,95\% Cl: $0.78,1.65, p=0.52$ ) and (RR: 0.96, $95 \%$ Cl: $0.44,2.10, p=0.92$ ) respectively.

\footnotetext{
* Correspondence: a_elhenawy@hotmail.com

${ }^{1}$ Division of Cardiac Surgery, Department of Surgery, Faculty of Medicine and Dentistry, University of Alberta, Edmonton, Alberta, Canada

${ }^{2}$ Division of Cardiothoracic Surgery, Al Azhar University, Cairo, Egypt

Full list of author information is available at the end of the article
}

(c) The Author(s). 2021 Open Access This article is licensed under a Creative Commons Attribution 4.0 International License, which permits use, sharing, adaptation, distribution and reproduction in any medium or format, as long as you give appropriate credit to the original author(s) and the source, provide a link to the Creative Commons licence, and indicate if changes were made. The images or other third party material in this article are included in the article's Creative Commons licence, unless indicated otherwise in a credit line to the material. If material is not included in the article's Creative Commons licence and your intended use is not permitted by statutory regulation or exceeds the permitted use, you will need to obtain permission directly from the copyright holder. To view a copy of this licence, visit http://creativecommons.org/licenses/by/4.0/ The Creative Commons Public Domain Dedication waiver (http://creativecommons.org/publicdomain/zero/1.0/) applies to the data made available in this article, unless otherwise stated in a credit line to the data. 


\begin{abstract}
(Continued from previous page)
Conclusions: With moderate certainty, due to the high risk of bias in some studies in one or two domains, we found intravenous iron supplementation is associated with a significant decrease in the blood transfusions rate, and modest hemoglobin concentrations rise when injected pre-surgery compared with placebo or oral iron supplementation. However, further full-scale randomized controlled trials with robust methodology are required. In particular, the safety, quality of life, and cost-effectiveness of different intravenous iron preparations require further evaluation.
\end{abstract}

Keywords: Intravenous iron therapy, Preoperative anemia, Major surgery

\section{Background}

Preoperative anemia remains the most common hematological deficit affecting the patients undergoing major surgery. It is an independent risk factor for perioperative allogeneic blood transfusion (ABT), as revealed in a meta-analysis of 949,445 patients [1] and associated with increased postoperative morbidity and mortality [2-5]. However, the evidence to support the treatment of anemia with transfusion in a perioperative setting is still lacking and requires further research. Recently, two large transfusion trigger meta-analyses reported different results. The first study reported similar mortality rates when a restrictive or liberal transfusion strategy was applied [6]. Unfortunately, this study investigated only the mortality outcome without reporting data on the morbidity occurrence post-transfusion, and their patients' populations are heterogeneous being a mixture of medical and surgical settings [6]. The second meta-analysis showed that the restrictive transfusion strategy was associated with less mortality and morbidity in the critical care arm of the study [7]. Interestingly, in the perioperative population, the restrictive transfusion strategy with transfusion triggers of $7-7.5 \mathrm{~g} / \mathrm{dL}$ may increase the risk of mortality. However, the investigators considered this finding of less robust evidence due to being insufficiently accumulated sample size compared with the critical care population recommending further research [7].

Furthermore, several literatures reported that blood transfusion is associated with adverse outcomes perioperatively [8-10]. Furthermore, data obtained from two large multicenter databases of 23,348 patients [11], and 227,425 patients [12] demonstrated that not only severe but also moderate/mild preoperative anemia is an independent risk factor for postoperative morbidity and 30-day mortality. These findings would suggest that approaches to reduce avoidable ABT might be associated with improved postoperative outcomes.

Although it is correctable [4], iron-deficiency anemia (IDA) remains the most frequent category of anemia that develops in patients undergoing major surgery $[13,14]$ due to inadequate iron intake and substantial blood loss perioperatively [15]. Oral iron supplementation requires a long time to replenish the exhausted iron stores and is associated with intolerability in about $70 \%$ of patients [16]. In contrast, intravenous (IV) iron supplementation allows for a large quantity of iron to be administered over a few doses and has excellent availability for erythropoiesis [17], to increase the hemoglobin $(\mathrm{Hb})$ concentration significantly in nonsurgical recent studies; a review [18], a randomized controlled trial (RCT) [19], and several metaanalyses [20-22].

Intravenous iron therapy for preoperative anemia has been tested in some RCTs. However, to date, the evidence to support its safety and efficacy is unclear. Due to the paucity of trials, most of which are of small sample size and have negative outcomes, which may be a result of being underpowered, there is insufficient evidence to support the use of IV iron to decrease ABT. A meta-analytic approach that pools these studies would aid in addressing the limitations of trial size, which would increase the power to observe statistically significant differences and may provide new and clinically useful evidence. This meta-analysis will investigate (a) the ability of parenteral iron administration to reduce $A B T$ requirement by improving preoperative $\mathrm{Hb}$ concentrations, and (b) the safety of parenteral iron in terms of mortality, morbidity, and adverse events (AEs) compared with placebo/ oral iron as the standard of care.

\section{Patients and methods}

\section{Protocol and registration}

Our study protocol has been published [23] and registered with the International Prospective Register of Systematic Reviews (PROSPERO), systematic review registration number: PROSPERO CRD42015016771) on February 16, 2015. Initially, following our published inclusion/exclusion criteria [23], we found only two eligible trials of small sample size. Consequently, to recruit more trials, we had to modify our inclusion/exclusion criteria (Additional File $1 \mathrm{~A}$ ) and made an update on the PROSPERO website on April 27, 2017. The current study was conducted following the Preferred Reporting Items for Systematic Reviews and Meta-analyses (PRISMA) statement [24] (Additional file 1 B).

\section{Eligibility criteria}

To be eligible, a study had to be a randomized or quasirandomized controlled clinical trial investigating adult 
surgical participants in which the intervention drug was IV iron as monotherapy, initiated/completed preoperatively. Being comprehensive, we did not apply any publication date/status or language restrictions.

\section{Search strategy}

With the help of a health sciences librarian, using our search strategy (Additional File $1 \mathrm{C}$ ), the following databases were searched: MEDLINE, EMBASE; EBM Reviews; the Cochrane-controlled trial registry in the Cochrane Library; Scopus; registries of health technology assessment and clinical trials; and Web of Science. In addition, we searched the ProQuest Dissertations and Theses database; the ClinicalTrials.gov website (National Institute of Health) for completed but unpublished studies; and Conference Proceedings Citation Index (CPCI)Science since 1990.

The search was started from the earliest retrievable date of each database to February 2019, supplemented by a manual search of reference lists of all retrieved trials, previous reviews of related areas, and Google engine. We ran an updated search on 26 October 2020, which came up with a pilot study in cardiac surgery [25], and a trial in abdominal surgery [26], and we decided to include both in our update.

\section{Study screening and data extraction}

Authors AE and SM conducted all study screening. Then, they reviewed the titles, abstracts, and reference lists of all included publications to retrieve potentially relevant studies. Full text of retrieved studies was subjected to a second phase of screening for eligibility as defined by the modified inclusion/exclusion criteria and study design for methodological quality. In cases of study eligibility disagreement occurred, a consensus was accomplished through discussion. The same two authors (AE and $\mathrm{SM}$ ) reviewed the relevant studies and extracted the relevant data using a structured form as per our protocol [23].

In our published protocols, the secondary outcomes were the number of units of blood or blood products transfused perioperatively, all-cause mortality, transfusionrelated acute lung injury, neurologic complications, adverse events, postoperative infections, cardiopulmonary complications, intensive care unit (ICU) admission/readmission, length of hospital stay, acute kidney injury, development of antibodies against platelets or white blood cells, post-transfusion purpura, graft vs. host disease, infection, immunomodulation, and iron overload. However, due to the absence/insufficient data from the primary trials, we were not able to achieve meta-analyses for some of the secondary outcomes.

On the other hand, other secondary outcomes that were not planned in our protocol as the health-related quality of life (HRQoL) measure as indicators for the quality of recovery post-surgery, the IDA parameters including reticulocyte (\%) percentage, mean corpuscular volume $(\mathrm{MCV})$, mean corpuscular hemoglobin $(\mathrm{MCH})$, and mean corpuscular hemoglobin concentration $(\mathrm{MCHC})$ were reported in this meta-analysis since we found such data published in the included trials.

\section{Assessment of the risk of bias}

The Cochrane Collaboration's tool (Additional File 1 D) was used [27] to evaluate the studies sources of bias.

\section{Data synthesis and analysis}

For primary outcomes, proportions of study participants who received an $\mathrm{ABT}$ was analyzed as risk ratios (RR) with their 95\% confidence intervals (CIs); in contrast, the hematopoietic response was analyzed as the mean difference (MD) with their 95\% CI for the Hb concentration change with its statistical significance between groups. Safety outcomes, including mortality, infection, and treatment-related AEs, were analyzed as RR with their $95 \%$ CIs.

Where standard deviation (SD) was not reported, the trial's authors were contacted in an effort to get the primary data to compute it. In the absence of SD information, SDs were estimated from $95 \%$ CIs, z-statistics, and $p$ values or imputed using the largest reported SD from other trials [28].

The Cochran's $Q$ test was used to calculate the statistical heterogeneity among studies. An $I^{2}$ value $\geq 40 \%$ suggests substantial statistical heterogeneity, and a random-effects model (DerSimonian and Laird technique) [29] was appropriate. With absent or low heterogeneity $\left(I^{2}\right.$ value $\left.<40 \%\right)$ [30], the fixed-effects model (Mantel-Haenszel technique) was appropriate, with a random-effects model as a sensitivity analysis. The $Z$ test was used to test the overall effect. We conducted a sensitivity analysis on our primary efficacy outcomes and safety outcome by excluding trials with a high risk of bias for one or more key domains [30]. In the analyses, to avoid moving the pooled estimate of IV iron treatment effect closer to null, initially, all trials reporting zero-event data for both trial arms were excluded from the analysis. Then, the analysis was repeated, including these trials to identify any change in the effect estimate as a sensitivity analysis, to provide a more valid estimate by having analytic consistency, and to offer more generalizability in the clinical practice by including all the available data [31]. Across the meta-analysis, the statistical significance was set as a $p$ value $<0.05$.

\section{Grading the strength of the evidence}

We judged the overall quality of evidence for each outcome in the involved trials using the Grading of 
Recommendations Assessment, Development, and Evaluation (GRADE) approach and created "Summary of findings" tables using GRADE Profiler (GRADEpro GDT) [32], following the guidance in the Cochrane Handbook for Systematic Reviews of Interventions [33]. Our GRADE judgment of certainty was achieved through consideration of these five domains: risk of bias, inconsistency, indirectness, imprecision, and publication bias.

\section{Subgroup analysis and exploration of heterogeneity}

To assess the heterogeneity, subgroup analyses were planned when feasible by having at least two studies in at least two subgroups for the primary outcome. The approach of "leave-one-out" sensitivity analysis was implemented to assess the stability of the meta-analysis outcomes [34].

RevMan 5.3 software: The Nordic Cochrane Centre, The Cochrane Collaboration; 2014 [35] was used to perform the analysis.

\section{Results}

The initial electronic search yielded 3195 citations. After reviewing the titles and abstracts, twenty-six studies were retrieved for more thorough screening, and a total of ten RCTs met our modified inclusion criteria (Additional File $1 \mathrm{~A}$ ), as shown in Fig. 1. In these ten studies, there was a total of 1039 participants (530 in the IV iron group and 509 in the control group). All patients were scheduled to have major surgery; two studies involved orthopedic surgery [36, 37], two involved cardiac surgery [38, 39], two involved gynecological surgery [40, 41], two involved colorectal surgery [42, 43], one involved major abdominal surgery [44], and one included a mixture of orthopedic, and cardiovascular surgery [45]. The trial's characteristics are summarized in Table 1 and Additional File $1 \mathrm{E}$.

All trials completed the full target dose of IV iron administration preoperatively except for two trials $[36,38]$ where the injection was initiated preoperatively, and the rest of the dose was completed after surgery. Each trial's iron injection regimen is detailed in Table 1 and Additional File $1 \mathrm{E}$.

The follow-up went beyond hospital discharge in four trials [37-39, 44]. The publication dates of the included trials ranged between 1999 [45] and 2017 [43].

\section{Risk of bias assessment}

Four [36, 38, 42, 43] of the ten trials were judged as having a low risk of bias across the entire set of domains,

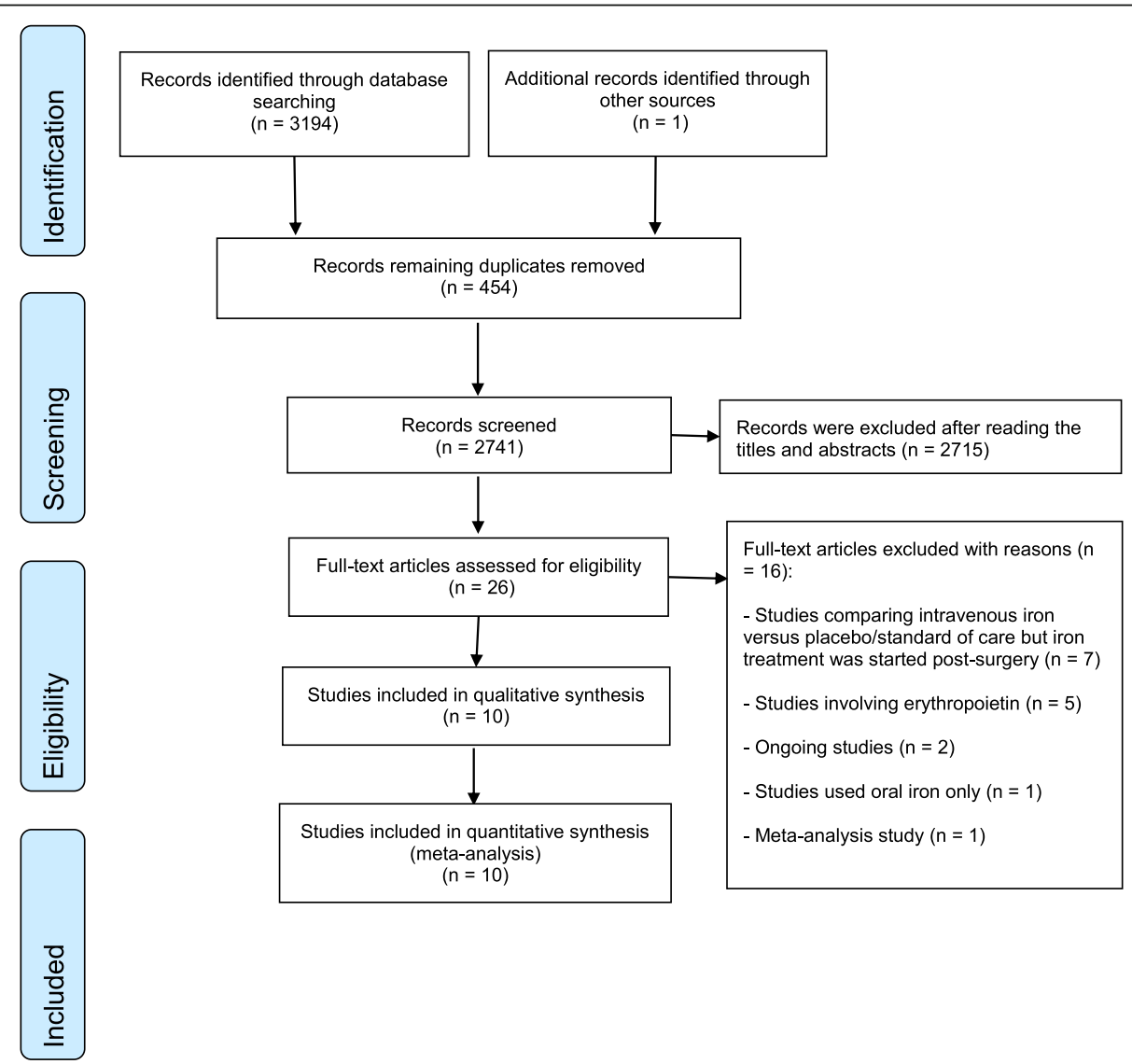

Fig. 1 Study flow chart 
Table 1 Summary characteristics of included studies

\begin{tabular}{|c|c|c|c|c|c|c|c|c|}
\hline $\begin{array}{l}\text { Study and } \\
\text { the } \\
\text { publication } \\
\text { year }\end{array}$ & Country & Surgery type & $\begin{array}{l}\text { Mean age } \\
\text { (SD): } \\
\text { intravenous } \\
\text { iron/control } \\
\text { or oral iron }\end{array}$ & $\begin{array}{l}\text { Patients' \#: } \\
\text { intravenous } \\
\text { iron/control } \\
\text { or oral iron }\end{array}$ & $\begin{array}{l}\text { Anemic } \\
\text { patients } \\
\text { were } \\
\text { recruited }\end{array}$ & Comparator & $\begin{array}{l}\text { Intravenous iron dosage } \\
\text { regimen }\end{array}$ & $\begin{array}{l}\text { Last } \\
\text { follow- } \\
\text { up time }\end{array}$ \\
\hline $\begin{array}{l}\text { Bernabeu- } \\
\text { Wittel et al., } \\
2016 \text { [37] }\end{array}$ & Spain & Hip fracture surgery & $\begin{array}{l}84.6 \pm 6.2 / \\
82.3 \pm 6.9\end{array}$ & $103 / 100$ & Yes & Placebo & $\begin{array}{l}1000 \text { mg of IV Ferric } \\
\text { carboxymaltose (two } 500 \mathrm{mg} \\
\text { vials diluted in a bottle of } 250 \\
\mathrm{~mL} \text { of saline after randomization } \\
\text { and always previously to } \\
\text { surgery. }\end{array}$ & $\begin{array}{l}60 \text { days } \\
\text { post- } \\
\text { hospital } \\
\text { discharge }\end{array}$ \\
\hline $\begin{array}{l}\text { Edwards } \\
\text { et al. } 2009 \\
{[42]}\end{array}$ & UK & $\begin{array}{l}\text { Colorectal cancer } \\
\text { resection }\end{array}$ & $\begin{array}{l}\text { 67/70 } \\
\text { (median) }\end{array}$ & $34 / 26$ & $\begin{array}{l}\text { Some } \\
\text { patients } \\
\text { were } \\
\text { anemic }\end{array}$ & Placebo & $\begin{array}{l}300 \mathrm{mg} \text { iron sucrose in } 2 \\
\text { infusions separated at least } 24 \mathrm{~h} \\
\text { apart, } 14 \text { days pre-surgery. }\end{array}$ & $\begin{array}{l}\text { Hospital } \\
\text { discharge }\end{array}$ \\
\hline $\begin{array}{l}\text { Froessler } \\
\text { et al. } 2016 \\
\text { [44] }\end{array}$ & Australia & $\begin{array}{l}\text { Major abdominal } \\
\text { surgery }\end{array}$ & $\begin{array}{l}64 \pm 15 / 68 \pm \\
15\end{array}$ & $40 / 32$ & Yes & Usual care & $\begin{array}{l}\text { Ferric carboxymaltose, } 15 \mathrm{mg} / \mathrm{kg} \\
\text { with maximum dose of } 1000 \mathrm{mg} \\
\text { between } 4 \text { and } 21 \text { days before } \\
\text { surgery. Post-surgery, within } 2 \\
\text { days of surgery, participants re- } \\
\text { ceived } 0.5 \mathrm{mg} \text { of ferric carboxy- } \\
\text { maltose per recorded } 1 \mathrm{~mL} \text { of } \\
\text { blood loss, if blood loss was > } \\
100 \mathrm{ml} \text {. }\end{array}$ & $\begin{array}{l}4 \text { weeks } \\
\text { post- } \\
\text { surgery. }\end{array}$ \\
\hline $\begin{array}{l}\text { Garrido- } \\
\text { Martín et al. } \\
2012 \text { [38] }\end{array}$ & Spain & Cardiac surgery & $\begin{array}{l}65 \pm 11 / 65 \pm \\
12\end{array}$ & $54 / 52$ & No & Placebo & $\begin{array}{l}\text { Three doses of iron sucrose } 100 \\
\mathrm{mg} / 24 \mathrm{~h} \text { during pre- and } \\
\text { postoperative hospitalization. }\end{array}$ & $\begin{array}{l}1 \text { month } \\
\text { post- } \\
\text { discharge }\end{array}$ \\
\hline $\begin{array}{l}\text { Johansson } \\
\text { et al. } 2015 \\
\text { [39] }\end{array}$ & Denmark & Cardiac surgery & $\begin{array}{l}65 \pm 8 / 65 \pm \\
11\end{array}$ & $30 / 30$ & No & Placebo & $\begin{array}{l}\text { A single-dose infusion of } 1000 \\
\mathrm{mg} \text { with a maximum single } \\
\text { dose of } 20 \mathrm{mg} / \mathrm{kg} \text {. The injection } \\
\text { was a day before surgery or } \\
\text { same day. }\end{array}$ & $\begin{array}{l}4 \text { weeks } \\
\text { after } \\
\text { surgery }\end{array}$ \\
\hline $\begin{array}{l}\text { Keeler et al. } \\
2017 \text { [43] }\end{array}$ & UK & $\begin{array}{l}\text { Colorectal cancer } \\
\text { resection }\end{array}$ & $\begin{array}{l}\text { Median (IQR) } \\
73.8(67.4- \\
78.6) / 74.7 \\
(67.9-80 \cdot 8)\end{array}$ & $55 / 61$ & Yes & Oral iron & $\begin{array}{l}\text { Ferric carboxymaltose with a } \\
\text { maximum dose of } 1000 \text { mg per } \\
\text { week and a maximum of } 2000 \\
\text { mg during the trial. The first } \\
\text { dose of injection was at least } 2 \\
\text { weeks pre-surgery. }\end{array}$ & $\begin{array}{l}2-3 \\
\text { months } \\
\text { post- } \\
\text { hospital } \\
\text { discharge }\end{array}$ \\
\hline $\begin{array}{l}\text { Kim et al. } \\
2009 \text { [40] }\end{array}$ & $\begin{array}{l}\text { South } \\
\text { Korea }\end{array}$ & $\begin{array}{l}\text { Gynecologic surgery } \\
\text { for menorrhagia }\end{array}$ & $\begin{array}{l}42.0 \pm 7.4 / \\
42.3 \pm 8.0\end{array}$ & $30 / 26$ & Yes & Oral iron & $\begin{array}{l}\text { A 200-mg dose of intravenous } \\
\text { iron sucrose three times a week } \\
\text { starting } 3 \text { weeks prior surgery } \\
\text { until target hemoglobin of } 10 \mathrm{~g} / \\
\mathrm{dL} \text { was achieved. The treatment } \\
\text { started } 3 \text { weeks pre-surgery. }\end{array}$ & $\begin{array}{l}\text { Hospital } \\
\text { discharge }\end{array}$ \\
\hline $\begin{array}{l}\text { Serrano- } \\
\text { Trenas et al. } \\
2011[36]\end{array}$ & Spain & $\begin{array}{l}\text { Hip fracture surgery } \\
\text { in elderly patients }\end{array}$ & $\begin{array}{l}83.46 \pm 7.1 / \\
82.53 \pm 6.4\end{array}$ & 99/97 & $\begin{array}{l}\text { Some } \\
\text { patients } \\
\text { were } \\
\text { anemic }\end{array}$ & $\begin{array}{l}\text { Standard } \\
\text { protocolized } \\
\text { treatment }\end{array}$ & $\begin{array}{l}\text { Iron sucrose } 200 \text { mg at } 48 \text {-hour } \\
\text { intervals for } 3 \text { doses, starting on } \\
\text { the day of admission; the first } \\
\text { dose was given pre-surgery. The } \\
\text { following doses were adminis- } \\
\text { tered before or after surgery, de- } \\
\text { pending on the time of surgery. }\end{array}$ & $\begin{array}{l}7 \text { days } \\
\text { post- } \\
\text { surgery }\end{array}$ \\
\hline $\begin{array}{l}\text { Shah et al. } \\
2016 \text { [41] }\end{array}$ & India & $\begin{array}{l}\text { Gynecologic surgery } \\
\text { for menorrhagia }\end{array}$ & $\begin{array}{l}\text { Most of ages } \\
\text { are between } \\
40 \text { and } 49 \\
\text { years }\end{array}$ & $55 / 55$ & Yes & Oral iron & $\begin{array}{l}\text { A } 100-\mathrm{mg} \text { dose of iron sucrose } \\
\text { in } 100 \mathrm{ml}(2 \text { ampoules) by slow } \\
\text { IV infusion. Starting 4-weeks pre- } \\
\text { surgery, the dose was repeated } \\
\text { on alternate day basis until tar- } \\
\text { get hemoglobin of } 10 \mathrm{~g} / \mathrm{dL} \text { was } \\
\text { achieved. }\end{array}$ & $\begin{array}{l}\text { Hospital } \\
\text { discharge }\end{array}$ \\
\hline $\begin{array}{l}\text { Weisbach } \\
\text { et al. } 1999 \\
\text { [45] }\end{array}$ & Germany & $\begin{array}{l}\text { Orthopedic or } \\
\text { cardio-vascular } \\
\text { surgery }\end{array}$ & $\begin{array}{l}64.4 \pm 14.7 / \\
64.1 \pm 9.5\end{array}$ & $30 / 30$ & No & Usual care & $\begin{array}{l}\text { A 200-mg dose of iron sucrose, } \\
\text { given after each donation and } \\
\text { at the enrolment before the first } \\
\text { donation. }\end{array}$ & $\begin{array}{l}\text { Hospital } \\
\text { discharge }\end{array}$ \\
\hline
\end{tabular}


while six trials [37, 39-41, 44, 45] were assessed to have an unclear or high risk of bias in one, or a maximum of two different domains. Details of the risk of bias judgment for each study are shown in Fig. 2, and itemspecific judgments for studies are presented in Additional File $1 \mathrm{D}$.

Except for only one trial [37] that did not provide detailed information on the methods used to achieve allocation concealment, all trials have proper random sequence generation and allocation concealment. Lack of blinding in this kind of study is less likely to generate bias when calculating measurable outcomes like transfusion rate, $\mathrm{Hb}$ and ferritin levels, or mortality. Moreover, when comparing IV iron with oral iron, blinding would be difficult due to the effect of oral iron on stool color.

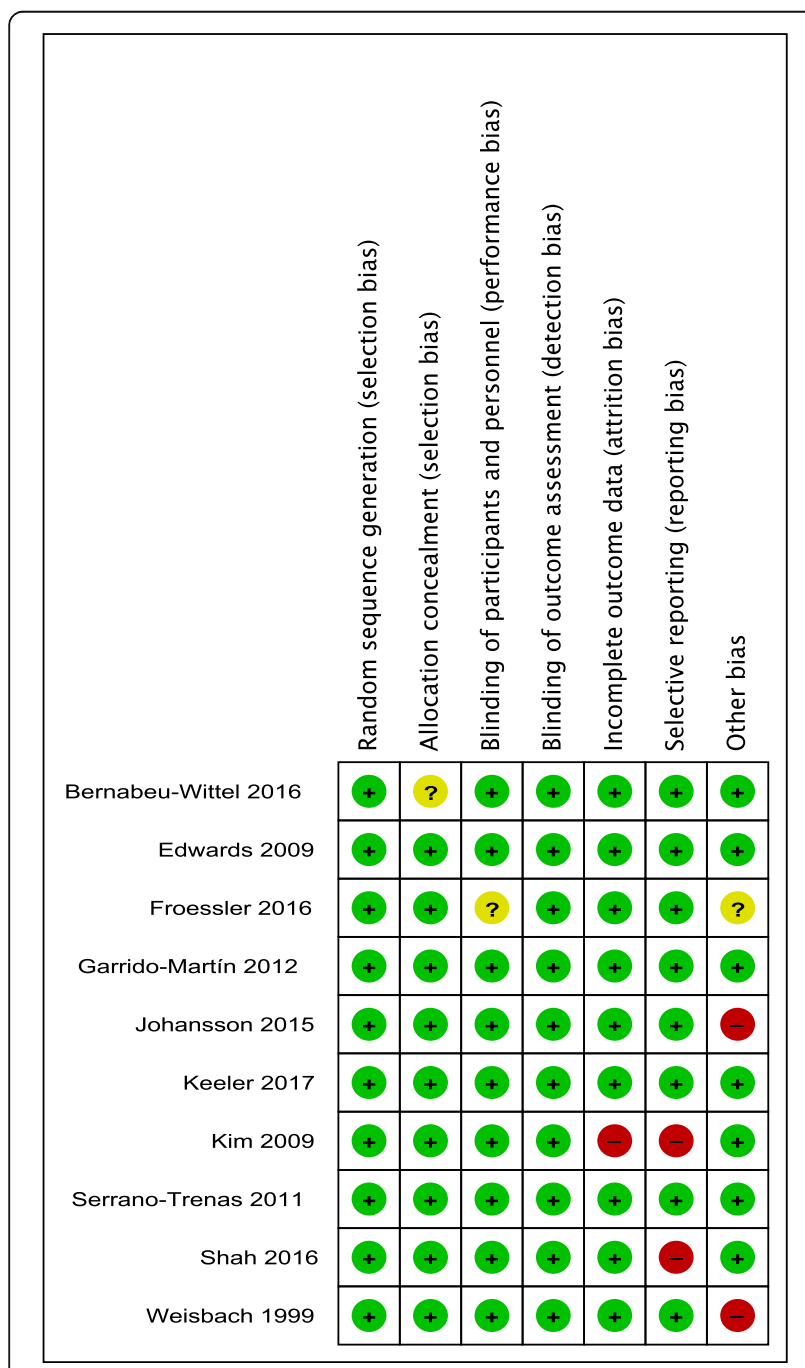

Fig. 2 Risk of bias summary shows the authors' judgment about each risk of bias item for each included study. The symbol " + " represents a low risk of bias, the symbol " -" represents a high risk of bias, and the symbol "?" represents an unclear risk of bias

\section{Exposure for allogeneic blood transfusion}

Overall, the proportion of transfused patients was 33\% in the IV iron versus $40 \%$ in the other group. Accordingly, IV iron injection showed significantly higher efficacy, achieving a reduction of $16 \%$ in the proportion of patients requiring ABT. This pooled effect estimate was statistically significant (RR between the study groups: $0.84,95 \%$ confidence interval $[\mathrm{CI}]: 0.71,0.99, p=0.04$ ) under the random-effects model (Fig. 3). Under the fixed-effects model, the reduction increased slightly to 17\% (RR: 0.83, 95\% CI: 0.70, 0.98, $p=0.03$ ) (Fig. 4). There was no statistical heterogeneity in ABT in either model, with a Cochran $Q$ statistic $(p=0.59)$ and a corresponding $I^{2}$ statistic of $0 \%$. As a sensitivity analysis, after excluding one study [45] designed mainly to improve autologous blood donation pre-surgery, the reduction of ABT increased slightly to $17 \%$ (RR: $0.83,95 \%$ CI: 0.70 , $0.98, p=0.02$ ) (Additional File $2 \mathrm{~A}$ : Figure 1).

However, a direct comparison between IV iron versus oral iron trials arms that included only three studies in the analysis was not able to find any transfusion rate difference (Fig. 5).

Given the different kinds of major surgeries using different IV iron preparations with dissimilar injection timing, subgroup analyses were conducted comparing cardiac [38, 39] versus non-cardiac studies [36, 37, 42-44], iron sucrose [36, 38, 42, 45] versus a ferric carboxymaltose IV iron preparation [37, 43, 44], and early injection ( $>2$ weeks pre-surgery) $[43,45]$ versus late injection of iron ( $\leq 2$ weeks of surgery) [36-39, 42, 44]. All analyses showed no statistically significant subgroup effect $(p=0.52, p=0.98$, and $p=0.56)$ respectively (Additional File 2 B: Figure 1-3).

Although we included ten trials, only eight studies [36-39, 42-45] reported transfusion data, so we were not able to conduct a meta-regression [30] or to explore publication bias by checking the funnel plot asymmetry [46] as this requires at least ten trials. Due to Hb measurement timing variability, we did not have ten studies contributing to the same time point analysis.

\section{Hemoglobin concentration change}

While the $\mathrm{Hb}$ levels $\mathrm{MD}$ of baseline-pooled estimate was comparable between groups (Additional File $2 \mathrm{C}$ : Figure 1 ), after completion of the preoperative IV iron administration, we found a significant $\mathrm{Hb}$ level increase in favor of the IV iron group (MD between groups: $7.15 \mathrm{~g} / \mathrm{L}, 95 \% \mathrm{CI}$ : $2.26,12.04, p=0.004$ ) (Fig. 6). Similarly, a direct comparison between IV iron versus oral iron participants revealed a significant $\mathrm{Hb}$ level rise in favor of the IV iron group (MD between groups: $7.63 \mathrm{~g} / \mathrm{L}, 95 \% \mathrm{CI}: 1.41,13.86, p=$ 0.02 ) when the analysis included five studies (Fig. 7). In following this increase difference at pre-surgery, the between-group difference dropped rapidly throughout the 


\begin{tabular}{|c|c|c|c|c|c|c|c|c|c|}
\hline \multirow[b]{2}{*}{ Study or Subgroup } & \multicolumn{2}{|c|}{ Intravenous iron } & \multicolumn{2}{|c|}{ Placebo/standard of care } & \multirow[b]{2}{*}{ Weight } & \multirow{2}{*}{$\begin{array}{c}\text { Risk Ratio } \\
\text { M-H, Random, } 95 \% \mathrm{Cl} \\
\end{array}$} & \multirow{2}{*}{\multicolumn{3}{|c|}{$\begin{array}{c}\text { Risk Ratio } \\
\text { M-H, Random, } 95 \% \mathrm{Cl}\end{array}$}} \\
\hline & Events & Total & Events & Total & & & & & \\
\hline \multicolumn{10}{|c|}{ 1.1.1 Subgroup analysis based on the dose amount of intravenous iron given } \\
\hline Bernabeu-Wittel 2016 & 53 & 103 & 54 & 100 & $39.3 \%$ & $0.95[0.73,1.24]$ & & & \\
\hline Edwards 2009 & 5 & 34 & 5 & 26 & $2.1 \%$ & $0.76[0.25,2.37]$ & & & \\
\hline Froessler 2016 & 5 & 40 & 10 & 32 & $2.9 \%$ & $0.40[0.15,1.05]$ & & & \\
\hline Garrido-Martin 2012 & 20 & 54 & 26 & 52 & $13.7 \%$ & $0.74[0.48,1.15]$ & & & - \\
\hline Johansson 2015 & 4 & 30 & 6 & 30 & $2.0 \%$ & $0.67[0.21,2.13]$ & & & \\
\hline Keeler 2017 & 10 & 55 & 14 & 61 & $5.1 \%$ & $0.79[0.38,1.64]$ & & & \\
\hline Serrano-Trenas 2011 & 44 & 99 & 54 & 97 & $33.4 \%$ & $0.80[0.60,1.06]$ & & - & - \\
\hline Weisbach 1999 & 6 & 30 & 3 & 30 & $1.6 \%$ & $2.00[0.55,7.27]$ & & & \\
\hline Subtotal $(95 \% \mathrm{Cl})$ & & 445 & & 428 & $100.0 \%$ & $0.84[0.71,0.99]$ & & & \\
\hline Total events & 147 & & 172 & & & & & & \\
\hline \multicolumn{10}{|c|}{ Heterogeneity: $\mathrm{Tau}^{2}=0.00 ; \mathrm{Chi}^{2}=5.56, \mathrm{df}=7(\mathrm{P}=0.59) ; \mathrm{I}^{2}=0 \%$} \\
\hline \multicolumn{10}{|c|}{ Test for overall effect: $Z=2.11(P=0.04)$} \\
\hline Total $(95 \% \mathrm{Cl})$ & & 445 & & 428 & $100.0 \%$ & $0.84[0.71,0.99]$ & & & \\
\hline Total events & 147 & & 172 & & & & & & \\
\hline \multicolumn{7}{|c|}{ Heterogeneity: $\mathrm{Tau}^{2}=0.00 ; \mathrm{Chi}^{2}=5.56, \mathrm{df}=7(P=0.59) ; \mathrm{I}^{2}=0 \%$} & 0.2 & 0.5 & 2 \\
\hline \multicolumn{7}{|c|}{ Test for overall effect: $Z=2.11(P=0.04)$} & 0.2 & Favours Intravenous iron & Favours Placebo/standard of care \\
\hline \multicolumn{10}{|c|}{ Test for subgroup differences: Not applicable } \\
\hline \multicolumn{10}{|c|}{$\begin{array}{l}\text { Fig. } 3 \text { Forest plot comparison shows the pooled comparison effect of intravenous iron therapy versus placebo/standard of care groups on the } \\
\text { proportion of the transfused patients (random effects model) }\end{array}$} \\
\hline
\end{tabular}

hospital stay, and there were no significant differences noted at the first postoperative day or hospital discharge time across groups (Additional File $2 \mathrm{C}$ : Figure 2-3).

Interestingly, post-hospital discharge, the pooled effect $[37-39,44]$ showed a significant increase in the Hb difference in favor of the IV iron group (MD between groups: $6.46 \mathrm{~g} / \mathrm{L}, 95 \% \mathrm{CI}$ : 3.10, 9.81, $p=0.0002$ ) (Fig. 8).

\section{Ferritin levels}

While the ferritin levels MD of baseline-pooled estimate was comparable between groups (Additional File 2-D: Figure 1), administration of IV iron was capable of causing marked improvements in the depleted iron stores replenishment in favor of the IV iron group at pre-surgery, hospital discharge, and > 4 weeks postoperatively, (MD between groups: $94.09 \mathrm{ng} / \mathrm{mL}, 95 \%$ CI: 51.57, 136.61, $p$
<0.0001), (MD between groups: $547.77 \mathrm{ng} / \mathrm{mL}, 95 \% \mathrm{CI}$ : 36.61, 1058.94, $p=0.04$ ), and (MD between groups: $347.57 \mathrm{ng} / \mathrm{mL}, 95$ \% CI: 290.92, 404.21, $p<0.00001)$ respectively (Additional File 2 D: Figure 2, 4 and 5). In addition, at pre-surgery time, a significant serum ferritin increase was obtained in favor of the IV iron group when it was compared directly with the oral iron group (MD between groups: $106.12 \mathrm{ng} / \mathrm{mL}, 95 \% \mathrm{CI}: 32.46$, 179.78, $p=0.005$ ), (Additional File 2 D: Figure 3).

\section{Iron-deficiency anemia blood tests}

For the rest of the IDA parameters, including reticulocyte (\%) percentage, MCV, hematocrit value (\%), transferrin saturation value (TSAT \%), $\mathrm{MCH}, \mathrm{MCHC}$, and serum iron level, only a few trials contributed to the different analyses (Additional File 2 D: Figure 6-24). In

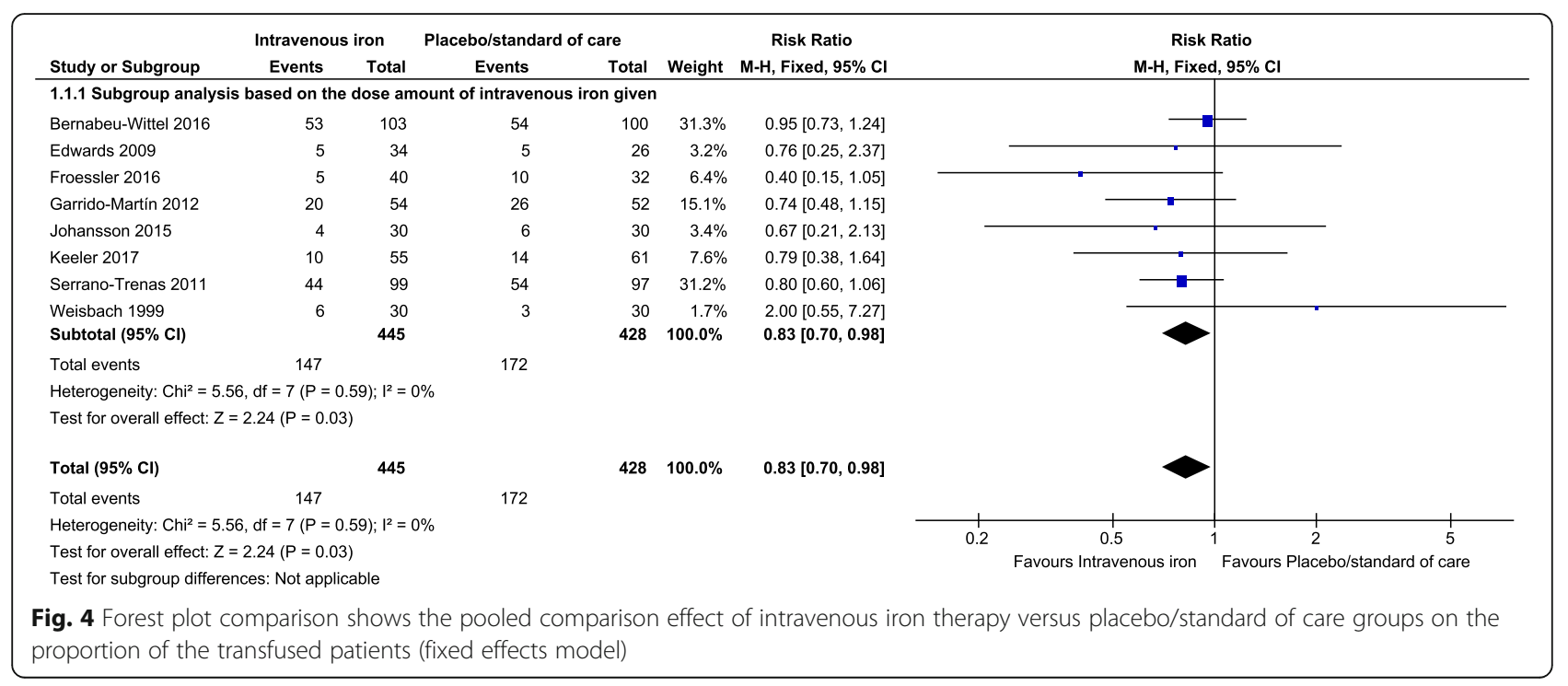




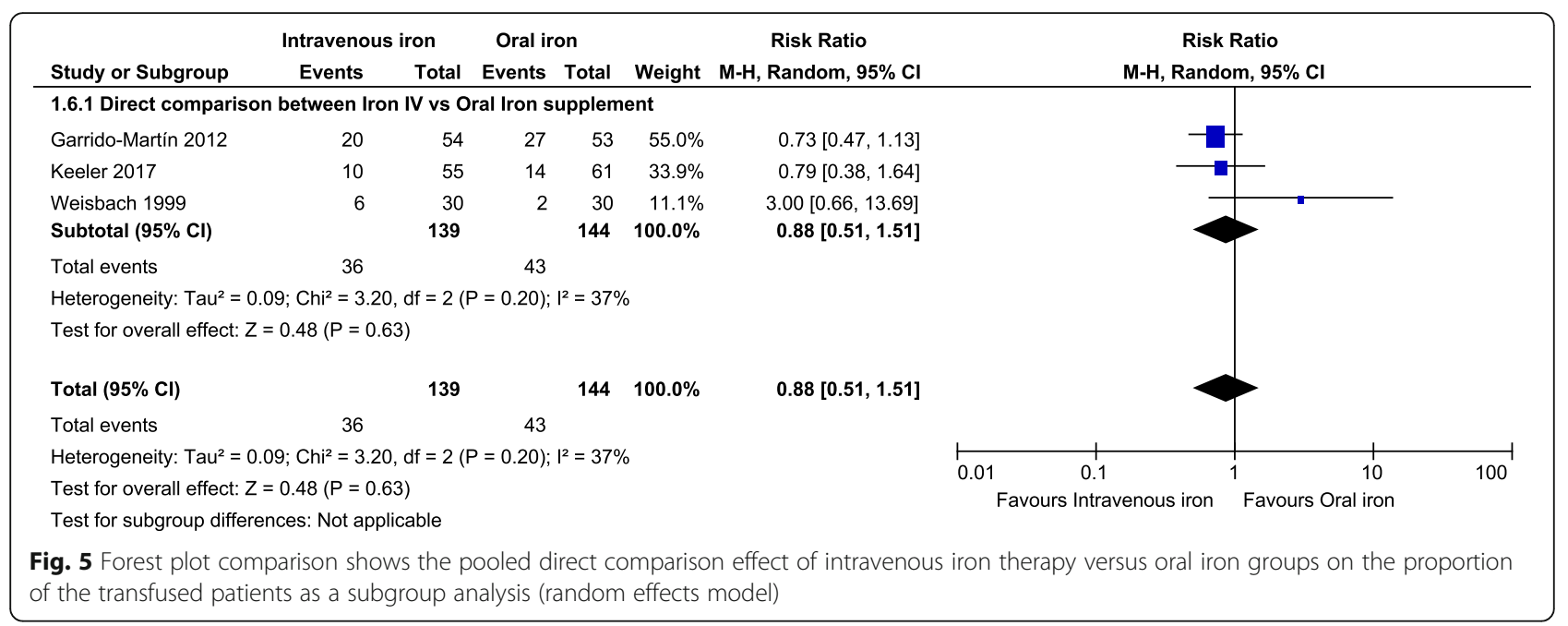

favor of the IV iron group, there are substantial increases in the reticulocyte percentage (at both presurgery time and hospital discharge time); and in the mean MCV level (at pre-surgery time). For the rest of these parameters, there was no significant change across groups after iron injection.

\section{Adverse events}

The participants tolerated IV iron injection well, and for non-serious (mild or moderate) AEs, there was no difference across groups (RR: 1.13, 95\% CI: 0.78, 1.65, p = 0.52 (Additional File 2 E: Figure 1). After including a trial of zero events [38] , the results remained similar [36-38, 40, 41, 43-45]. Regarding serious adverse effects (SAEs), similarly, there was no difference between groups (RR: $0.96,95 \% \mathrm{CI}: 0.44,2.10, p=0.92$ ) [39, 43] (Additional File $2 \mathrm{E}$ : Figure 2).

\section{Mortality}

There was no statistically significant difference between the two groups for the reported 30-day mortality (RR: $1.10,95 \%$ CI: 0.60, 2.00, $p=0.76$ ) [36, 37, 39, 44] (Additional File 2 E: Figure 3). Findings were alike after including a trial of zero events [39]. At 2 months post-hospital discharge, comparable death results (RR: 1.18, 95\% CI: 0.63, 2.19, $p=0.6$ ) were also obtained [37, 43] (Additional File 2 E: Figure 4).

\section{Infection}

Five trials [36-38, 43, 44] reported data for postoperative infection. One of these five studies [38] reported a similar infection rate between the trial arms but did not provide numbers. Another study [36] reported the total infection rate across the study (14.8\%) but did not provide arm-specific numbers of infections. A third study [43] reported no difference in infection rate $(p=0.091)$ or grade of its severity $(p=0.083)$ between the trial arms but did not provide numbers. The other two studies [37, 44] showed similar infection incidence between groups (RR: 0.64, 95\% CI: 0.30, 1.40, $p=0.27$ ) (Additional File 2 E: Figure 5).

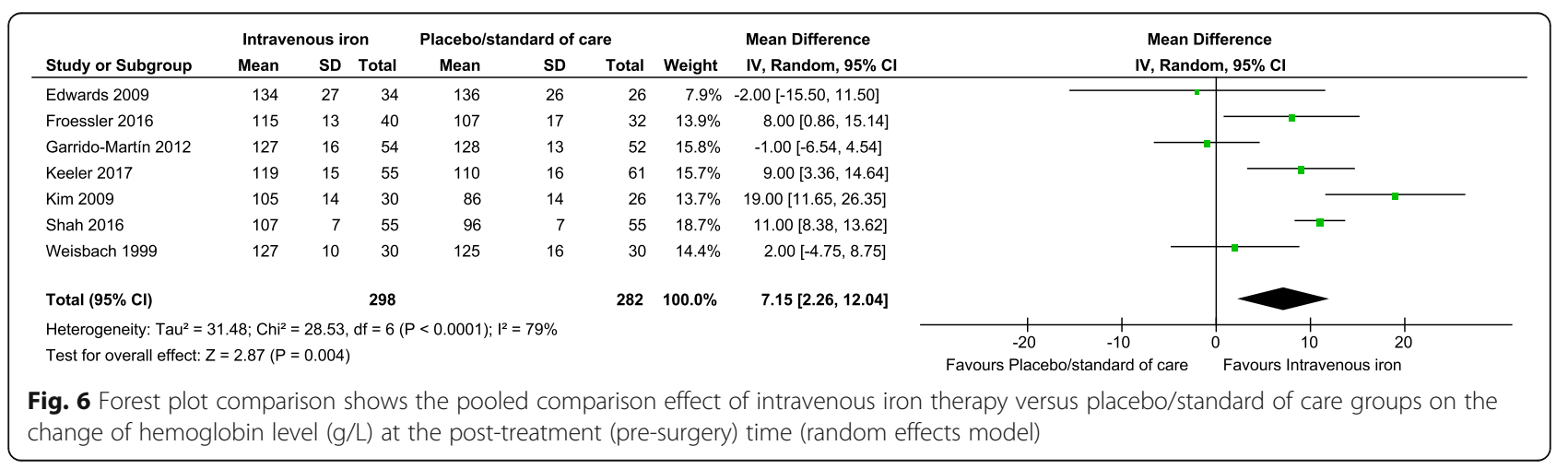




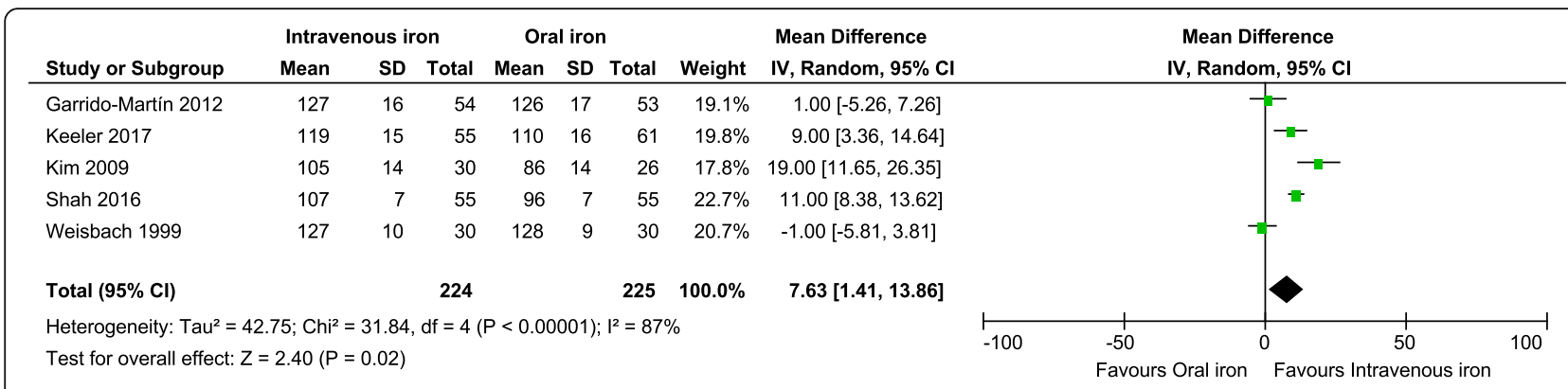

Fig. 7 Forest plot comparison shows the pooled comparison effect of intravenous iron therapy versus oral iron groups on the change of hemoglobin level $(\mathrm{g} / \mathrm{L})$ at the post-treatment (pre-surgery) time (random effects model)

\section{Hospital length of stay}

Five trials [36, 37, 42-44] reported data about hospital LOS. However, none of the individual studies showed a statistical difference across the trial arms, and we were not able to pool them as four trials [37, 42-44] provided the LOS as median days.

\section{Quality of life}

Health-related quality of life data were provided in only two trials [37, 44] that used two different tests, which makes quantitative analysis not feasible. The first trial [37] used the Short Form 36 Version 2 for acute patients (SF-36v2) [47], at 60 days post-hospital discharge reassessment; it revealed statistically non-significant and clinically unimportant changes. Similar findings were observed in the second trial [44] that used the short form health survey (SF36) [48] at 4 weeks post-surgery reassessment.

\section{Discussion}

The core finding of this meta-analysis, based on moderate-quality evidence, was a $16 \%$ reduction in the ABT for the participants who received the iron injection (Additional File 3). In addition, pre-surgery $\mathrm{Hb}$ and ferritin levels increase accompanied by $\mathrm{ABT}$ reduction, with no change in postoperative infections, $\mathrm{AE}$, or mortality rate.

For transfusion rate reduction, the minimal clinically significant difference (MCID) cutoff has not been established yet. However, the largest currently ongoing trial investigating iron injection to treat preoperative anemia in major surgery used a risk reduction of $12 \%$ in the transfusion rate to calculate the sample size [49]. Therefore, in this meta-analysis, it would seem that after receiving IV iron, a reduction of $16 \%$ in the proportion of patients requiring $\mathrm{ABT}$ might be considered clinically important and sufficient to change patient management. This transfusion reduction in our study is in accordance with previous large meta-analysis of both surgical and nonsurgical RCTs [50], a recent surgical meta-analysis [51], several observational studies [52-61], and a pooled analysis of observational data from 2547 patients [62]. This finding is of great benefit for all patients, including Jehovah's Witness (JW) patients, where ABT is forbidden, patients who will be potentially organ recipients, patients for whom transfusions are medically contraindicated, and those who are living in countries with restricted resources.

In the current meta-analysis, we included trials from different surgical specialties that allow for extended external validity; however, these findings may not be generalizable to patient populations other than those undergoing elective surgery. In particular, the findings from this meta-analysis conflict with a recent trial in critical care patients [63], and a meta-analysis in pregnancy [20]. In these two studies, although the $\mathrm{Hb}$ levels were significantly higher after IV iron therapy, there were no significant differences in blood transfusion

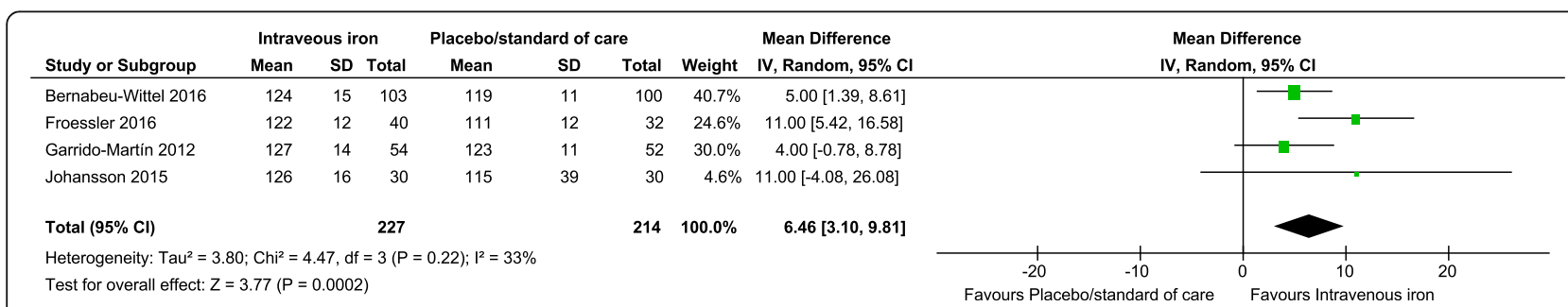

Fig. 8 Forest plot comparison shows the pooled comparison effect of intravenous iron therapy versus placebo/standard of care groups on the change of hemoglobin level $(\mathrm{g} / \mathrm{L})$ as follow-up $>4$ weeks postoperatively (random effects model) 
between groups [20,63]. Moreover, a recent critical care meta-analysis [64] reported no difference in ABT requirements or $\mathrm{Hb}$ level change at short-term (up to 10 days) or mid-term follow-up between groups after IV iron treatment. In the latter meta-analysis, findings were limited by considerable heterogeneity between trials, including the nature of interventions and the risks of bias in the included studies. More recently, in surgical settings, two meta-analyses did not show evidence of transfusion reduction in non-elective surgery [65], or when iron injected postoperatively [66], indicating the importance of injecting iron pre-surgery by sufficient time.

In our meta-analysis, although there was no statistical heterogeneity as $I^{2}$ was zero\% in both random and fixedeffects models, there was a discrepancy in ABT reduction rate between the two models that could ensue due to type I error indicating a shortage of power to identify trials' heterogeneity. However, the clinical heterogeneity of trials was explored using sensitivity and subgroup analyses. Our subgroup analyses were conducted by comparing cardiac $[38,39]$ versus non-cardiac surgeries [36, 37, 42-44], iron sucrose [36, 38, 42, 45] versus carboxymaltose IV iron preparation [37, 43, 44], and early $[43,45]$ versus delayed iron injection [36-39, 42, 44]. Interestingly, none of these analyses showed any statistically significant subgroup influence to modify the effect of IV iron. We think that this analysis may not be able to identify subgroup differences due to a smaller number of studies/participants and/or uneven covariate distribution, producing uncertainty in the results.

Interestingly, in our meta-analysis, the $\mathrm{Hb}$ increase tendency had a bi-phasic pattern composed of two waves. This pattern rise might be related to the IV iron timing variability of administration either early (2-5 weeks before the operation) in some trials $[40-43,45]$ or late (around surgery time) in other trials [36-39, 44]. The disappearance of the first wave might be related to the attenuation/termination of the IV iron effect and/or the substantial perioperative acute blood loss. One study [44] that administered about a thousand grams of the IV iron 4-21 days pre-surgery in addition to extra doses of IV iron increments postoperatively contributed to a positive effect in the pooled estimate in both $\mathrm{Hb}$ rise waves indicating the importance of the early and second dose of IV iron injection. Overall, this detected $\mathrm{Hb}$ increase in our meta-analysis is consistent with two feasibility studies $[67,68]$, and several observational studies $[53,56,69-71]$, where IV iron was given pre-surgery. Moreover, our $\mathrm{Hb}$ increase pattern over time is in line with a very recent surgical meta-analysis where IV iron was capable of augmenting $\mathrm{Hb}$ level. This increase was higher when it was measured at 2 to 4 weeks of followup $(\mathrm{MD}=5.69 \mathrm{~g} / \mathrm{L}, 95 \% \mathrm{CI}: 2.11-9.27)$, but not when calculated earlier [66] supporting a previous surgical trial that showed IV iron achieved an increase at 4 weeks after IV iron administration [72]. These findings, and ours, suggest that iron injection should be initiated about 4 weeks pre-surgery and continued till surgery using a second dose with at least a week interval from the first injection in order to achieve a long and sustained effect to stimulate the erythropoiesis on time to protect against $\mathrm{ABT}$ through moving the peak effect to be at the perioperative time [53, 70].

The other observation was that the $\mathrm{Hb}$ rise did not happen when the trial's participants received a total dose of $\leq 600 \mathrm{mg}$ of IV iron [36, 38, 42], only the rise occurred significantly when a higher dose of iron was injected [37, 39-41, 43, 44], demonstrating a pattern of positive dose-response relationship supporting the recent consensus recommendation to give a dose between 1000 and $1500 \mathrm{mg}$ of IV iron in one or two divided doses [73]. As our meta-analysis is for the RCTs, it would be plausible to infer a causal relationship between iron injection and $\mathrm{Hb}$ increase tendency. Accordingly, we think that patients who receive a total dose of $<1000 \mathrm{mg}$ of iron or who are injected only around the time of surgery would not respond as well as those receive larger dose administered at least 2 weeks pre-surgery.

In our meta-analysis, although the $\mathrm{Hb}$ rise by $7.15 \mathrm{~g} / \mathrm{L}$ is statistically significant, this rise is still considered below the defined clinical meaningful hemoglobinconcentration increase $(\geq 1 \mathrm{~g} / \mathrm{dL})$ [74]. Interestingly, this modest $\mathrm{Hb}$ increase was associated with meaningful transfusion reduction.

Another observation is that the ferritin rise peak was at hospital discharge time preceding the second wave of the $\mathrm{Hb}$ rise as iron replenishment is a process that happens before $\mathrm{Hb}$ formation. These data support other investigators' findings $[53,70]$. Another finding we found was the reticulocyte percentage/count increase posttreatment and during the hospital stay, demonstrating a continued recent bone marrow activity to prepare for the second wave appearance.

We did not find a significant difference in AEs occurrence between the groups, although six trials [37, 39-41, 43 , 44] injected doses of $\geq 1000$ to $2000 \mathrm{mg}$ of iron in one trial [43]. This finding is in harmony with nonsurgical trials using up to $2000 \mathrm{mg}$ [75] or $2500 \mathrm{mg}$ of IV iron [76], two surgical meta-analyses [65, 77], a meta-analysis in IDA [78], and surgical observational studies [56, 79]. The chief AEs related to IV iron administration in our study were erythema with pain/itching at the injection site, phlebitis, discomfort, fever, and dizziness. Nausea, vomiting, constipation, and diarrhea were more frequent in those participants who received oral iron.

Given the relatively small sample size of each trial and the relative rarity of severe side effects as the anaphylactic 
shock reactions, there is a need for a large-scale phase III clinical trial or a large observational report to study the incidence of the AEs of IV iron. However, according to the United States Death Certificate Registry, only three mortalities were coded as "AEs in therapeutic use of iron preparation" over the period between 1979 and 2006 [80], and the actual anaphylaxis was very rare [16].

In this meta-analysis, the iron injection did not change our study mortality, LOS, or postoperative infection rates, consistent with a recent surgical meta-analysis [65].

\section{Strengths of the study}

This meta-analysis protocol was registered and published. We followed the recommendations of the Cochrane collaboration and PRISMA statement. Our search was comprehensive without having any time, language, or IV iron preparation restrictions. It has broad external generalizability for many surgical subspecialties. As it included only RCTs, it provides high-quality evidence in practice. All analyses were performed using both fixed-effect and random-effect models. When in between-study heterogeneity exists, both techniques may be biased, but random-effects models will be more conservative.

\section{Limitations of the study}

The first limitation is some of the included studies recruited non-anemic patients, which would bias their findings toward the null. Second, the current study findings may not be generalizable to younger patients undergoing major surgery as eight of the ten trials had a mean/median age above 64 years old. Only two gynecological studies investigated younger female patients experiencing menorrhagia; a condition that usually exists at a younger age. A third potential limitation of this meta-analysis is the relatively smaller sample size of most of the trials that necessitate careful interpretation of the reported side effects of IV iron since more extensive studies are needed to identify side effects. The fourth limitation is that we estimated/imputed SD for trials when these were not published. This could be a source of bias, although the alternative would have been to exclude those trials. Doing so would have resulted in a smaller sample size of this meta-analysis and would have introduced another kind of bias that would have made the interpretation of findings difficult.

\section{Conclusion}

Based on moderate-quality evidence, our results are in support of preoperative intravenous iron administration to reduce the likelihood of allogeneic blood transfusion and to provide a modest increase in hemoglobin concentration in major surgery settings. This evidence came from eight trials for the transfusion proportion and seven trials for the hemoglobin change.

Similarly, with moderate-quality evidence, a greater increase in serum ferritin pre-surgery was found post iron injection.

Low-quality evidence suggests that surgical patients tolerate the non-serious adverse events of intravenous iron supplementation. However, with high-quality evidence, no evidence suggests that iron injection decreases mortality.

However, our findings did not show the superiority of parenteral iron therapy over oral iron on the proportion reduction of the transfused patients as a subgroup analysis. Accordingly, new trials could be made to have a robust evidence-body, and we recommend a robust clinical trial testing the hypothesis that an optimally timed injected iron in a large dose $(1500-2000 \mathrm{mg})$ is safe to counteract acute perioperative blood loss.

\section{Supplementary Information}

The online version contains supplementary material available at https://doi. org/10.1186/s13643-021-01579-8.

Additional file 1. A: Modified Article Selection Criteria. B: PRISMA Checklist. C: Search Strategy. D: Risk of Bias Assessment. E: Characteristics of Included Studies' Tables.

Additional file 2. A: Forest-plots for the Sensitivity Analysis. B: Forestplots for the Subgroup Analysis. C: Forest-plots for Hemoglobin Values at Different Time Points. D: Forest-plots for the Different Iron-deficiency Anemia Blood Tests. E: Forest-plots for the Safety Endpoints of Intravenous Iron versus Placebo or Oral Iron.

Additional file 3. Summary of Findings Table.

\section{Abbreviations}

ABT: Allogeneic blood transfusion; IDA: Iron-deficiency anemia; IV: Intravenous; Hb: Hemoglobin; RCT: Randomized controlled trial; AEs: Adverse events; PROSPERO: Prospective Register of Systematic Reviews; PRISMA: Preferred Reporting Items for Systematic Reviews and Meta-analyses; CPCl: Conference Proceedings Citation Index; RR: Risk ratios; Cls: Confidence intervals; MD: Mean difference; SD: Standard deviation; MCV: Mean corpuscular volume; TSAT\%: Transferrin saturation value; MCH: Mean corpuscular hemoglobin; MCHC: Mean corpuscular hemoglobin concentration; SAEs: Serious adverse effects; LOS: Hospital length of stay; HRQoL: Health-related quality of life; SF-36v2: Short form 36 version 2 for acute patients; SF36: Short form health survey; MCID: The minimal clinically important difference; JW: Jehovah Witness

\section{Acknowledgements}

Dr. Bagshaw is supported by a Canada Research Chair in Critical Care Nephrology. The authors thank Mrs. Trish Chatterley, a Collections Manager at John W. Scott Health Sciences Library at the University of Alberta, for her support in devising our search strategy. Also, we thank Ms. Laila Elhenawy, a student in the Psychology Department at the University of Alberta, for her help conducting the evidence table from the included trials as double checkers for the numbers to eliminate the human being errors in the metaanalysis.

\section{Authors' contributions}

All data in the current study were collected and synthesized by Dr. Elhenawy, with Dr. Meyer serving as an independent second reviewer. Dr. Elhenawy conducted all statistical analyses and wrote the entire manuscript. Dr. Meyer, Dr. Bagshaw, and Dr. Carroll guided during the progress of the study. All authors read and approved the final meta-analysis. 


\section{Authors' information}

Abdelsalam M. Elhenawy, MD, MSc (Surg), MSc (Epi), Ph.D (Surg)—has been involved with cardiac valves, heart/lung transplantation, mechanical circulatory support, trans-apical cardiac valve replacement, and ischemic mitral regurgitation surgery, research and publications.

Steven R. Meyer, MD, Ph.D—has been involved with lung and heart transplantation research, mechanical circulatory support, trans-apical cardiac valve replacement, blood conservation strategies, and evidence-based medicine.

Sean. M. Bagshaw, MD, MSc - has been involved in prospective clinical trials, systematic reviews, meta-analysis, and production of clinical guidelines in critical care nephrology.

Roderick G MacArthur, MD, MSc — has been involved with complex aortic arch, lung and heart transplantation, mechanical circulatory support research, and surgery.

Linda Carroll, PhD—has been involved with observational studies, systematic reviews and meta-analyses, methods development, and clinical guideline development in the areas of neck pain, whiplash, traumatic brain injury, catastrophic traffic injuries, depression, and multiple sclerosis.

\section{Availability of data and materials}

Study protocol: available at www.crd.york.ac.uk/prospero (PROSPERO: (RD42018098604)

\section{Ethics approval and consent to participate}

Not applicable.

\section{Consent for publication}

Not applicable.

\section{Competing interests}

The authors declare that they have no competing interests.

\section{Author details}

'Division of Cardiac Surgery, Department of Surgery, Faculty of Medicine and Dentistry, University of Alberta, Edmonton, Alberta, Canada. ${ }^{2}$ Division of Cardiothoracic Surgery, Al Azhar University, Cairo, Egypt. ${ }^{3}$ Division of Critical Care Medicine, Faculty of Medicine and Dentistry, University of Alberta, Edmonton, Alberta, Canada. ${ }^{4}$ School of Public Health, University of Alberta, Edmonton, Alberta, Canada.

\section{Received: 4 May 2020 Accepted: 2 January 2021}

Published online: 23 January 2021

\section{References}

1. Fowler AJ, Ahmad T, Phull MK, Allard S, Gillies MA, Pearse RM. Meta-analysis of the association between preoperative anaemia and mortality after surgery. Br J Surg. 2015;102(11):1314-24.

2. Boening A, Boedeker RH, Scheibelhut C, Rietzschel J, Roth P, Schonburg M. Anemia before coronary artery bypass surgery as additional risk factor increases the perioperative risk. Ann Thorac Surg. 2011;92(3):805-10.

3. Miceli A, Romeo F, Glauber M, de Siena PM, Caputo M, Angelini GD. Preoperative anemia increases mortality and postoperative morbidity after cardiac surgery. J Cardiothorac Surg. 2014:9:137 8090-9-137.

4. Yanes Vidal GJ. Anemia in candidates for heart surgery. Rev Esp Anestesiol Reanim. 2015:62(Suppl 1):69-75.

5. Mueller MM, Van Remoortel H, Meybohm P, Aranko K, Aubron C, Burger R, Carson JL, Cichutek K, De Buck E, Devine D, Fergusson D, Follea G, French C, Frey KP, Gammon R, Levy JH, Murphy MF, Ozier Y, Pavenski K, So-Osman C, Tiberghien P, Volmink J, Waters JH, Wood EM, Seifried E. ICC PBM Frankfurt 2018 Group: Patient blood management: recommendations from the 2018 frankfurt consensus conference. JAMA. 2019;321(10):983-97.

6. Trentino KM, Farmer SL, Leahy MF, Sanfilippo FM, Isbister JP, Mayberry R, Hofmann A, Shander A, French C, Murray K. Systematic reviews and metaanalyses comparing mortality in restrictive and liberal haemoglobin thresholds for red cell transfusion: an overview of systematic reviews. BMC Med. 2020;18(1):154 020-01614-w.

7. Chong MA, Krishnan R, Cheng D, Martin J. Should transfusion trigger thresholds differ for critical care versus perioperative patients? A metaanalysis of randomized trials. Crit Care Med. 2018;46(2):252-63.
8. Trentino KM, Leahy MF, Sanfilippo FM, Farmer SL, Hofmann A, Mace H, Murray K. Associations of nadir haemoglobin level and red blood cell transfusion with mortality and length of stay in surgical specialties: a retrospective cohort study. Anaesthesia. 2019;74(6):726-34.

9. Paone G, Brewer R, Theurer PF, Bell GF, Cogan CM, Prager RL, Michigan Society of Thoracic and Cardiovascular Surgeons. Preoperative predicted risk does not fully explain the association between red blood cell transfusion and mortality in coronary artery bypass grafting. J Thorac Cardiovasc Surg. 2012;143(1):178-85.

10. Hopewell S, Omar O, Hyde C, Yu LM, Doree C, Murphy MF. A systematic review of the effect of red blood cell transfusion on mortality: Evidence from large-scale observational studies published between 2006 and 2010. BMJ Open. 2013:3(5):e002154.

11. Leichtle SW, Mouawad NJ, Lampman R, Singal B, Cleary RK. Does preoperative anemia adversely affect colon and rectal surgery outcomes? J Am Coll Surg. 2011;212(2):187-94.

12. Musallam K, Tamim H, Richards T, Spahn DR, Rosendaal FR, Habbal A, Khreiss M, Dahdaleh FS, Khavandi K, Sfeir PM, Soweid A, Hoballah JJ, Taher AT, Jamali FR. Preoperative anaemia and postoperative outcomes in non-cardiac surgeny: A retrospective cohort study. Lancet. 2011;378(9800):1396-407.

13. Spahn DR, Schoenrath F, Spahn GH, Seifert B, Stein P, Theusinger OM, Kaserer A, Hegemann I, Hofmann A, Maisano F, Falk V. Effect of ultra-shortterm treatment of patients with iron deficiency or anaemia undergoing cardiac surgery: a prospective randomised trial. Lancet. 2019;393(10187): 2201-12.

14. Guralnik JM, Eisenstaedt RS, Ferrucci L, Klein HG, Woodman RC. Prevalence of anemia in persons 65 years and older in the united states: evidence for a high rate of unexplained anemia. Blood. 2004;104(8):2263-8.

15. Laso-Morales MJ, Vives R, Vallejo-Tarrat A, Calo N, Valle-Beltran A, Pontes C. Single dose of intravenous ferric carboxymaltose infusion versus multiple fractionated doses of intravenous iron sucrose in the treatment of postoperative anaemia in colorectal cancer patients: Study protocol for a randomised controlled trial. Trials. 2019;20(1):23 -018-3125-2.

16. Deloughery TG. Safety of oral and intravenous iron. Acta Haematol. 2019. 142(1):8-12.

17. Charytan C, Levin N, Al-Saloum M, Hafeez T, Gagnon S, Van Wyck DB Efficacy and safety of iron sucrose for iron deficiency in patients with dialysis-associated anemia: North American clinical trial. Am J Kidney Dis. 2001;37(2):300-7.

18. Lebrun F, Klastersky J, Levacq D, Wissam Y, Paesmans M. Intravenous iron therapy for anemic cancer patients: a review of recently published clinical studies. Support Care Cancer. 2017;25(7):2313-9.

19. Bhavi SB, Jaju PB. Intravenous iron sucrose $v / s$ oral ferrous fumarate for treatment of anemia in pregnancy. A randomized controlled trial. BMC Pregnancy Childbirth. 2017;17(1):137 017-1313-9.

20. Lewkowitz AK, Gupta A, Simon L, Sabol BA, Stoll C, Cooke E, Rampersad RA, Tuuli MG. Intravenous compared with oral iron for the treatment of irondeficiency anemia in pregnancy: a systematic review and meta-analysis. J Perinatol. 2019:39(4):519-32.

21. Govindappagari S, Burwick RM. Treatment of iron deficiency anemia in pregnancy with intravenous versus oral iron: systematic review and metaanalysis. Am J Perinatol. 2019;36(4):366-76.

22. Aksan A, Isik H, Radeke HH, Dignass A, Stein J. Systematic review with network meta-analysis: comparative efficacy and tolerability of different intravenous iron formulations for the treatment of iron deficiency anaemia in patients with inflammatory bowel disease. Aliment Pharmacol Ther. 2017; 45(10):1303-18.

23. Elhenawy AM, Meyer SR, Bagshaw SM, MacArthur RG, Carroll LJ. Role of preoperative intravenous iron therapy to correct anemia before major surgery: study protocol for systematic review and meta-analysis. Syst Rev. 2015:4:29 015-0016-4.

24. Moher D, Liberati A, Tetzlaff J, Altman DG, PRISMA Group. Preferred reporting items for systematic reviews and meta-analyses: the PRISMA statement. Int J Surg. 2010;8(5):336-41.

25. Padmanabhan H, Siau K, Nevill AM, Morgan I, Cotton J, Ng A, Brookes MJ, Luckraz H. Intravenous iron does not effectively correct preoperative anaemia in cardiac surgery: a pilot randomized controlled trial. Interact Cardiovasc Thorac Surg. 2019:28(3):447-54.

26. Richards T, Baikady RR, Clevenger B, Butcher A, Abeysiri S, Chau M, Macdougall IC, Murphy G, Swinson R, Collier T, Van Dyck L, Browne J, Bradbury A, Dodd M, Evans R, Brealey D, Anker SD, Klein A. Preoperative 
intravenous iron to treat anaemia before major abdominal surgery (PREVEN TT): a randomised, double-blind, controlled trial. Lancet. 2020;396:1353-61.

27. Higgins JP, Altman DG, Gotzsche PC, Juni P, Moher D, Oxman AD, Savovic J, Schulz KF, Weeks L, Sterne JA, Cochrane Bias Methods Group, Cochrane Statistical Methods Group. The cochrane collaboration's tool for assessing risk of bias in randomised trials. BMJ. 2011;343:d5928.

28. Follmann D, Elliott $P$, Suh I, Cutler J. Variance imputation for overviews of clinical trials with continuous response. J Clin Epidemiol. 1992;45(7):769-73.

29. DerSimonian R, Laird N. Meta-analysis in clinical trials. Control Clin Trials. 1986;7(3):177-88.

30. Higgins J, Green S. Cochrane handbook for systematic reviews of interventions Version 5.1.0 [updated march 2011]. version 5.1.0 ed. Higgins JPT GS, editor. The Cochrane Collaboration; 2011. Available from: www. cochrane-handbook.org. [Internet. Accessed 13 Sept 2013].

31. Friedrich JO, Adhikari NK, Beyene J. Inclusion of zero total event trials in meta-analyses maintains analytic consistency and incorporates all available data. BMC Med Res Methodol. 2007;7:5.

32. GRADEpro GDT. McMaster University (developed by Evidence Prime). GRAD Epro GDT. Version accessed 12 Dec 2018. Hamilton (ON): McMaster University (developed by Evidence Prime); 2015.

33. Schünemann H, Oxman A, Vist G, Higgins J, Deeks J, Glasziou P, et al. Chapter 12: Interpreting results and drawing conclusions. In: Cochrane handbook for systematic reviews of interventions Version 5.1.0 [updated March 2011]. Edited by Higgins J, Green S. The Cochrane Collaboration; 2011. Available from: http://handbook.cochrane.org/chapter_12/12 interpreting_results_and_drawing_conclusions.htm. [Internet. Accessed 13 Sept 2013].

34. Tobias A. Assessing the influence of a single study in the meta-analysis estimate. Stata Techn Bull. 1999;8:15-7.

35. The Nordic Cochrane Centre. The Cochrane Collaboration.: RevMan 5.3 beta | Informatics \& Knowledge Management Department. 5.3.3. Copenhagen: The Nordic Cochrane Centre, The Cochrane Collaboration; 2014.

36. Serrano-Trenas JA, Ugalde PF, Cabello LM, Chofles LC, Lazaro PS, Benitez PC. Role of perioperative intravenous iron therapy in elderly hip fracture patients: a single-center randomized controlled trial. Transfusion. 2011;51(1):97-104.

37. Bernabeu-Wittel M, Romero M, Ollero-Baturone M, Aparicio R, MurciaZaragoza J, Rincon-Gomez M, Monte-Secades R, Melero-Bascones M, Rosso CM, Ruiz-Cantero A, PAHFRAC-01 Investigators. Ferric carboxymaltose with or without erythropoietin in anemic patients with hip fracture: a randomized clinical trial. Transfusion. 2016;56(9):2199-211.

38. GarridoMartin P, NassarMansur MI, de la LlanaDucros R, VirgosAller TM, Rodriguez Fortunez PM, AvalosPinto R, JimenezSosa A, MartinezSanz R. The effect of intravenous and oral iron administration on perioperative anaemia and transfusion requirements in patients undergoing elective cardiac surgery: a randomized clinical trial. Interact Cardiovasc Thoracic Surg. 2012; 15(6):1013-8.

39. Johansson PI, Rasmussen AS, Thomsen LL. Intravenous iron isomaltoside 1000 (monofer $(\mathrm{R}))$ reduces postoperative anaemia in preoperatively nonanaemic patients undergoing elective or subacute coronary artery bypass graft, valve replacement or a combination thereof: a randomized doubleblind placebo-controlled clinical trial (the PROTECT trial). Vox Sang. 2015; 109(3):257-66.

40. Kim YH, Chung HH, Kang SB, Kim SC, Kim YT. Safety and usefulness of intravenous iron sucrose in the management of preoperative anemia in patients with menorrhagia: a phase IV, open-label, prospective, randomized study. Acta Haematol. 2009;121(1):37-41.

41. Shah J, Vachhanai A, Mehta M, Kongnathi S. Safety and effectiveness of intravenous iron sucrose versus oral iron: a study among preoperative anemic women with menorrhagia. Natl J Commun Med. 2016;7(1):60-3.

42. Edwards T, Noble E, Durran A, Mellor N, Hosie K. Randomized clinical trial of preoperative intravenous iron sucrose to reduce blood transfusion in anaemic patients after colorectal cancer surgery. Br J Surg. 2009;96(10): $1122-8$.

43. Keeler BD, Simpson JA, Ng O, Padmanabhan H, Brookes MJ, Acheson AG, IVICA Trial Group. Randomized clinical trial of preoperative oral versus intravenous iron in anaemic patients with colorectal cancer. Br J Surg. 2017; 104(3):214-21.

44. Froessler $\mathrm{B}, \mathrm{PP}, \mathrm{WI}, \mathrm{HN}, \mathrm{SR}, \mathrm{ME}$. The important role for intravenous iron in perioperative patient blood management in major abdominal surgery: a randomized controlled trial. Ann Surg. 2016;264(1):41-6.
45. Weisbach V, Skoda P, Rippel R, Lauer G, Glaser A, Zingsem J, Zimmermann $R$, Eckstein R. Oral or intravenous iron as an adjuvant to autologous blood donation in elective surgery: a randomized, controlled study. Transfusion. 1999;39(5):465-72.

46. Sterne JA, Sutton AJ, loannidis JP, Terrin N, Jones DR, Lau J, Carpenter J, Rucker G, Harbord RM, Schmid CH, Tetzlaff J, Deeks JJ, Peters J, Macaskill P, Schwarzer G, Duval S, Altman DG, Moher D, Higgins JP. Recommendations for examining and interpreting funnel plot asymmetry in meta-analyses of randomised controlled trials. BMJ. 2011;343:d4002.

47. Ware JE, Kosinski M, Gandek B. New England Medical Center Hospital. SF-36 health survey: manual and interpretation guide. Boston, Mass: The Health Institution, New England Medical Center Hospital; 2002.

48. Ware JE Jr, Sherbourne CD. The MOS 36-item short-form health survey (SF-36). I. conceptual framework and item selection. Med Care. 1992;30(6):473-83.

49. Richards T, Clevenger B, Keidan J, Collier T, Klein AA, Anker SD, Kelly JD. PREVENTT: preoperative intravenous iron to treat anaemia in major surgery: study protocol for a randomised controlled trial. Trials. 2015;16:254 0150774-2.

50. Litton E, Xiao J, Ho KM. Safety and efficacy of intravenous iron therapy in reducing requirement for allogeneic blood transfusion: systematic review and meta-analysis of randomised clinical trials. BMJ. 2013;347:f4822.

51. Schack A, Berkfors AA, Ekeloef S, Gogenur I, Burcharth J. The effect of perioperative iron therapy in acute major non-cardiac surgery on allogenic blood transfusion and postoperative haemoglobin levels: a systematic review and meta-analysis. World J Surg. 2019;43(7):1677-91.

52. Quinn EM, Meland E, McGinn S, Anderson JH. Correction of iron-deficiency anaemia in colorectal surgery reduces perioperative transfusion rates: a before and after study. Int J Surg. 2017;38:1-8.

53. Calleja JL, Delgado S, del Val A, Hervas A, Larraona JL, Teran A, Cucala M, Mearin F, Colon Cancer Study Group. Ferric carboxymaltose reduces transfusions and hospital stay in patients with colon cancer and anemia. Int J Colorectal Dis. 2016;31(3):543-51.

54. Laso-Morales M, Gomez R, Pontes G, Díaz EC, Munoz M. Intravenous versus oral iron for treating iron deficiency anaemia in colorectal cancer patients: a single-centre, observational cohort study. Transfusion Medicine. 2016; 26(Suppl. 1):53.

55. Blanco Rubio N, Llorens Eizaguerri M, Seral Garcia B, Burillo Fuertes P, Ranera Garcia M, Albareda Albareda J. Preoperative intravenous iron as a strategy for blood saving in surgery for hip fracture. Med Clin (Barc). 2013;141(9): $371-5$.

56. Laso-Morales M, Jerico C, Gomez-Ramirez S, Castellvi J, Viso L, Roig-Martinez I, Pontes C, Munoz M. Preoperative management of colorectal cancerinduced iron deficiency anemia in clinical practice: data from a large observational cohort. Transfusion. 2017;57(12):3040-8.

57. Diaz Espallardo C, Laso Morales MJ, Colilles Calvet C, Mora Lopez L, Roig Martinez I, Martinez Marin MT. The multidisciplinary approach is useful for optimising preoperative haemoglobin in colorectal cancer surgery. Cir Esp. 2011;89(6):392-9.

58. Bisbe E, Garcia-Erce JA, Diez-Lobo Al, Munoz M, Anaemia Working Group Espana. A multicentre comparative study on the efficacy of intravenous ferric carboxymaltose and iron sucrose for correcting preoperative anaemia in patients undergoing major elective surgery. Br J Anaesth. 2011;107(3): 477-8.

59. Diez-Lobo A, Fisac-Martín M, Bermejo-Aycar I, Munoz M. Preoperative intravenous iron administration corrects anemia and reduces transfusion requirement in women undergoing abdominal hysterectomy. Transfus Altern Med. 2007;9(2):114-9.

60. Cuenca J, Garcia-Erce JA, Martinez AA, Solano VM, Molina J, Munoz M. Role of parenteral iron in the management of anaemia in the elderly patient undergoing displaced subcapital hip fracture repair: preliminary data. Arch Orthop Trauma Surg. 2005;125(5):342-7.

61. Cuenca J, Garcia-Erce JA, Munoz M, Izuel M, Martinez AA, Herrera A. Patients with pertrochanteric hip fracture may benefit from preoperative intravenous iron therapy: a pilot study. Transfusion. 2004; 44(10):1447-52.

62. Munoz M, Gomez-Ramirez S, Cuenca J, Garcia-Erce JA, Iglesias-Aparicio D, Haman-Alcober S, Ariza D, Naveira E. Very-short-term perioperative intravenous iron administration and postoperative outcome in major orthopedic surgery: a pooled analysis of observational data from 2547 patients. Transfusion. 2014;54(2):289-99. 
63. IRONMAN Investigators, Litton E, Baker S, Erber WN, Farmer S, Ferrier J, French C, Gummer J, Hawkins D, Higgins A, Hofmann A, De Keulenaer B, McMorrow J, Olynyk JK, Richards T, Towler S, Trengove R, Webb S, Australian and New Zealand Intensive Care Society Clinical Trials Group. Intravenous iron or placebo for anaemia in intensive care: The IRONMAN multicentre randomized blinded trial: a randomized trial of IV iron in critical illness. Intensive Care Med. 2016;42(11):1715-22.

64. Shah A, Roy NB, McKechnie S, Doree C, Fisher SA, Stanworth SJ. Iron supplementation to treat anaemia in adult critical care patients: a systematic review and meta-analysis. Crit Care. 2016;20(1):306.

65. Shah A, Palmer AJR, Fisher SA, Rahman SM, Brunskill S, Doree C, Reid J, Sugavanam A, Stanworth SJ. What is the effect of perioperative intravenous iron therapy in patients undergoing non-elective surgery? A systematic review with meta-analysis and trial sequential analysis. Perioper Med (Lond). 2018:7:30 018-0109-4. eCollection 2018.

66. Perelman I, Winter R, Sikora L, Martel G, Saidenberg E, Fergusson D. The efficacy of postoperative iron therapy in improving clinical and patientcentered outcomes following surgery: a systematic review and metaanalysis. Transfus Med Rev. 2018;32(2):89-101.

67. Simpson J, Ng S, Brookes M, Acheson A. Single dose preoperative administration of intravenous iron corrects iron deficiency anaemia in colorectal cancer. J Blood Disord Transfus. 2010;1(1):1000101. https://doi.org/ $10.4172 / 2155-9864$.

68. Keeler BD, Simpson JA, Ng S, Tselepis C, lqbal T, Brookes MJ, Acheson AG. The feasibility and clinical efficacy of intravenous iron administration for preoperative anaemia in patients with colorectal cancer. Colorectal Dis. 2014;16(10):794-800

69. Munoz M, Garcia-Erce JA, Diez-Lobo Al, Campos A, Sebastianes C, Bisbe E, Anaemia Working Group Espana (AWGE). Usefulness of the administration of intravenous iron sucrose for the correction of preoperative anemia in major surgery patients. Med Clin (Barc). 2009;132(8):303-6.

70. Theusinger OM, Leyvraz PF, Schanz U, Seifert B, Spahn DR. Treatment of iron deficiency anemia in orthopedic surgery with intravenous iron: efficacy and limits: a prospective study. Anesthesiology. 2007;107(6):923-7.

71. Wilson MJ, Dekker JW, Bruns E, Borstlap W, Jeekel J, Zwaginga JJ, Schipperus M. Short-term effect of preoperative intravenous iron therapy in colorectal cancer patients with anemia: results of a cohort study. Transfusion. 2018; 58(3):795-803

72. Khalafallah AA, Yan C, Al-Badri R, Robinson E, Kirkby BE, Ingram E, Gray Z, Khelgi $V$, Robertson IK, Kirkby BP. Intravenous ferric carboxymaltose versus standard care in the management of postoperative anaemia: a prospective, open-label, randomised controlled trial. Lancet Haematol. 2016;3(9):e415-25.

73. Munoz $M$, Acheson AG, Auerbach $M$, Besser $M$, Habler $O$, Kehlet $H$, Liumbruno GM, Lasocki S, Meybohm P, Rao Baikady R, Richards T, Shander A, So-Osman C, Spahn DR, Klein AA. International consensus statement on the peri-operative management of anaemia and iron deficiency. Anaesthesia. 2017;72(2):233-47.

74. Mouysset JL, Freier B, van den Bosch J, Levaché CB, Bols A, Tessen HW, Belton L, Bohac GC, Terwey JH, Tonini G. Hemoglobin levels and quality of life in patients with symptomatic chemotherapy-induced anemia: the eAQUA study. Cancer Manag Res. 2016:8:1-10

75. Evstatiev R, Marteau P, Iqbal T, Khalif IL, Stein J, Bokemeyer B, Chopey IV, Gutzwiller FS, Riopel L, Gasche C, FERGI Study Group. FERGlcor, a randomized controlled trial on ferric carboxymaltose for iron deficiency anemia in inflammatory bowel disease. Gastroenterology. 2011;141(3):84653 e1-2.

76. Van Wyck DB, Martens MG, Seid MH, Baker JB, Mangione A. Intravenous ferric carboxymaltose compared with oral iron in the treatment of postpartum anemia: a randomized controlled trial. Obstet Gynecol. 2007; 110(2 Pt 1):267-78

77. Shin HW, Park JJ, Kim HJ, You HS, Choi SU, Lee MJ. Efficacy of perioperative intravenous iron therapy for transfusion in orthopedic surgery: a systematic review and meta-analysis. PLoS One. 2019;14(5):e0215427.

78. Avni T, Bieber A, Grossman A, Green H, Leibovici L, Gafter-Gvili A. The safety of intravenous iron preparations: systematic review and meta-analysis. Mayo Clin Proc. 2015;90(1):12-23.
79. Torres S, Kuo YH, Morris K, Neibart R, Holtz JB, Davis JM. Intravenous iron following cardiac surgery does not increase the infection rate. Surg Infect (Larchmt). 2006;7(4):361-6.

80. Wysowski DK, Swartz L, Borders-Hemphill BV, Goulding MR, Dormitzer C. Use of parenteral iron products and serious anaphylactic-type reactions. Am J Hematol. 2010;85(9):650-4.

\section{Publisher's Note}

Springer Nature remains neutral with regard to jurisdictional claims in published maps and institutional affiliations.
Ready to submit your research? Choose BMC and benefit from:

- fast, convenient online submission

- thorough peer review by experienced researchers in your field

- rapid publication on acceptance

- support for research data, including large and complex data types

- gold Open Access which fosters wider collaboration and increased citations

- maximum visibility for your research: over $100 \mathrm{M}$ website views per year

At BMC, research is always in progress.

Learn more biomedcentral.com/submissions 